\title{
An Analysis of Code Switching in Dialogue of the Indonesian Novel Permainan Maut by Lexie Xu
}

\author{
Ni Putu Diana Yosi", I Gede Sadia \\ English Department, Faculty of Arts- Udayana University \\ [dianayosi21@gmail.com], [gede.sadia@unud.ac.id] \\ Denpasar, Bali, Indonesia \\ *Corresponding Author
}

\begin{abstract}
This undergraduate thesis entitled "Analysis of Code Switching in Dialogue of Indonesian Novel Permainan Maut by Lexie Xu" has two aims; they are to analyze the types of code switching and the functions of code switching found in the novel. The data source used in this study is a novel entitled Permainan Maut by Lexie Xu. It was chosen as the data source because there are many characters who come from different social backgrounds that make them often talk in various languages. This phenomenon could help analyze how code switching works in every dialogue. The data were collected using documentation method and analyzed using the theory proposed by Wardhaugh (1986) in his book entitled An Introduction to Sociolinguistics; the types of code switching were analyzed using the theory proposed by Appel \& Muysken (1987) in his book entitled Language Contact and Bilingualism. The analysis is presented using informal method. The result of this study shows that Situational Code Switching is more dominantly used than Metaphorical code switching. Not all the functions of code switching were found in these dialogues. Only four out of six were used, they are: Referential Function, Metalinguistic Function, Phatic Function and Expressive Function.
\end{abstract}

Keywords: code switching, types of code switching, function of code switching, novel.

\begin{abstract}
Abstrak
Makalah ini yang berjudul "Analysis of Code Switching in Dialogue of Indonesian Novel Permainan Maut by Lexie Xu" memiliki dua tujuan, yaitu: untuk menganalisis tipe-tipe kode alih bahasa dan fungsi-fungsi dari kode alih bahasa yang ditemukan di dalam sebuah novel. Sumber data yang digunakan dalam analisis ini adalah sebuah novel berbahasa Indonesia berjudul Permainan Maut oleh Lexie Xu. Data ini dipilih dikarenakan banyaknya karakter di dalam novel tersebut yang berasal dari berbagai latar belakang sosial yang berbeda. Hal tersebut menyebabkan mereka sering kali berbicara menggunakan lebih dari satu bahasa. Fenomena ini dapat membantu dalam menganalisis bagaimana cara kerja alih bahasa di dalam
\end{abstract}


setiap dialog dalam novel tersebut. Data ini dikumpulkan menggunakan metode dokumentasi dan dianalisis menggunakan teori dari Wardhaugh (1986) yang diambil dari bukunya yang berjudul An Introduction to Sociolinguistics untuk menganalisis tipe-tipe alih bahasa dan teori selanjutnya yang digunakan adalah teori dari Appel \& Muysken (1987) dengan bukunya yang berjudul Language Contact and Bilingualism untuk mengnalisis fungsi-fungsi dari kode alih bahasa. Selanjutnya, analysis dalam tesis ini disampaikan dengan menggunakan metode informal dengan menggunakan kata-kata dalam menjelaskan tipe-tipe dan fungsi-fungsi dari kode alih bahasa yang digunakan oleh setiap karakter di dialog mereka. Hasil dari analisis ini menjelaskan bahwa Situational Code Switching lebih banyak digunakan dibandingkan dengan Metaphorical Code Switching. Tidak semua dari fungsi-fungsi kode alih bahasa dapat ditemukan di dalam novel ini. Hanya empat dari enam yang digunakan, yaitu: Referential Function, Metalinguistic Function, Phatic Function and Expressive Function.

Kata kunci: alihbahasa, tipe-tipe kode alih bahasa, fungsi-fungsi alih bahasa, novel.

\section{Background of the Study}

Code switching is part of sociolinguistics which talks about how language is being switched from one to another in one utterance. The particular dialect or language one choose to use on any occasion is a code, a system used for communication between one or more parties (Wardhaugh, 2006;101). The term switching here means the way or how the language is changed from one to another different language. This phenomenon where the society is often to switch their language when they are having a conversation is called Code Switching. This is inclined to happen in an area where its speaker speaks more than one code or as we know a bilingual. To differentiate each other, code switching has several types and reasons why the speaker does switch the language in their utterance. According to Wardhaugh, R. (1986) there are two types of code switching; they are Situational Code Switching and Metaphorical Code Switching. The lack of vocabulary is often to be one of the reasons why people switch their language.

This is an interesting topic to be analyzed due to the phenomenon of bilingualism that we can find in almost everywhere. In this era, finding someone who speaks only one language is something hard to do because usually parents nowadays teach their children more than one language even when they just learn how to speak. This can lead to language switching when they are speaking or having a conversation with someone who is bilingual too. Some people wonder why bilinguals switch their language when they can speak one language and make it convenient. This study helps analyze the type and reason behind the language switching happening in one of the most favorite literary works among the teenagers.

\section{Problems of the Study}

To know what kind of code switching is used by them along with its reason, the problems can be concluded by asking a few questions as follows: 
a. What are the types of code switching used in every dialogue?

b. What are the functions of code switching used by the characters based on the theory?

\section{Aims of the Study}

There are two purposes of this writing that can be achieved based on the problems stated above. The aims can be formulated as follows:

a. To analyze what types of code switching are used in every dialogue.

b. To analyze the functions why the characters in the novel switches their language from one to another.

\section{Research Method}

The method of research has an important role to support the analysis of the data. Without doing any method or arranging any steps, research cannot be done. The steps used in this research method are data source, method and technique of collecting data and the last is method and technique of analyzing data.

\subsection{Data Source}

The data used in this study were taken from an Indonesian novel entitled Permainan Maut by Lexie Xu. Lexie Xu is a mom of one son who was born in Pontianak, Indonesia on October $14^{\text {th }}$. Lexie $\mathrm{Xu}$ likes to write a story with mystery or thriller as its genre. This Indonesian novel is chosen because Indonesian writer especially writes novel about teenage life and tends to use more than one language to express her imagination. The story of this novel also explains about teenagers who come from different societies and different backgrounds of life. There are so many characters that have different backgrounds of life which happen to appear in this story such as a character that is mix-blooded and there is also a character who studies abroad that makes her have a mixed culture. Based on this reason, code switching happens because of the characters tend to be affected by two cultures or more. Another reason to choose Indonesian novel is the languages used in Indonesian novel are usually Indonesian-English which is easily understood and it helps to give a better analysis.

\subsection{Method and Technique of Collecting Data}

The data of this study were collected using documentation method. There are several steps in collecting the data; they are first, the novel was read to find code switching especially in the dialogues. Second, the code switching in the dialogue was marked and highlighted. After marking and highlighting the dialogue, the last step was note taking every code switching found.

\subsection{Method and Technique of Analyzing Data}

The data were analyzed using descriptive and qualitative method using the theory proposed by Wardhaugh (1986) for the types of code switching and proposed by Appel \& Muysken (1987) for the functions of code switching. The collected data were categorized based on the types of codeswitching using the theory proposed by Wardhaugh (1986) and were analyzed based on the function of code-switching using the theory proposed by Appel \& Muysken (1987).

\subsection{Method and Technique of Presenting Analysis}

The data analysis is presented in using informal method. It defines what type and reason or function of code switching used by the characters in their dialogue. Due to the amount of code switching found in every dialogue, a table is used to group the sentences and 
furthermore, they are categorized based on their types and reasons. The data are explained afterwards.

\section{Analysis Types and Functions of Code Switching in the Dialogues of Indonesian Novel Permainan Maut by Lexie Xu}

As what has been explained in the theoretical framework above, there are two types of codes witching and six functions of code switching. The analysis of each type and function of codeswitching used in this novel is presented as follows:

\subsection{The Analysis of Types of Code Switching}

The data is focused on the dialogue in the novel. To analyze each type of code switching, the theory proposed by Wardhaugh (1986) was applied. It says that there are two types of code switching, they are: Situational Code Switching and Metaphorical Code Switching.

\subsubsection{The Analysis of Situational Code Switching \\ According to Wardhaugh} (1986:102), "Situational code-switching occurs when the languages used change according to the situations in which the conversants find themselves: they speak one language in one situation and another in a different one. No topic change is involved." This type of code switching happens when the conversants suddenly change their language use according to the situation where they are in without changing the topic..

\section{Data 1:}

Tony: "Tapi agak-agak nggak sopan juga, ngedobrak masuk ke kamar pengurus rumah pada jam begini."
Markus: "Yah, kita pake cara gentleman dong, coy."

Tony: "Cara gentleman? Emang caranya seperti apa?"

Markus: "Ngetuk pintu, bego." (Chapter 4 , page 66)

(Tony: "But it is quite rude too if we break in to the room of housekeeper at this hour.

Markus: "We break in in a gentleman way of course."

Tony: "In a gentleman way? How?"

Markus: "Knock the door. Dummy.") (Chapter 4, page 66)

Analysis:

This short conversation between Tony and Markus explains how Situational Code Switching works. It clearly shows up when Tony starts asking how to break in to the room in a gentleman way. "Cara gentleman? Emang caranya seperti apa?" ("In a gentleman way? How?") in this sentence, show how the language shifts from the first sentence to the other. Apart from the language, the situation between them also changes. In the first sentence Tony said "Cara gentleman?" shows the situation where Tony only repeats Markus' word as a surprising react with the idea he gave him. The second one, when Tony said "Emangnya caranya seperti apa?" has different situation from the first sentence. The situation explained through this sentence is the situation where Tony asks about the example of gentleman way suggested by Markus because he has no idea about it. Moreover, when the situation between the sentences changes, a topic change is not required. Both the sentences said by Tony still have the same topic, that is the gentleman way that is suggested by Markus. 


\subsubsection{The Analysis of Metaphorical Code Switching \\ According to Wardhaugh} (1986:103) "When a change of topic requires a change in the language used we have metaphorical code-switching. The interesting point here is that some topics may be discussed in either code, but the choice of code adds a distinct flavor to what is said about the topic." This type of Code Switching happens when the conversant does not only change the situation, but also the topic between the two sentenced which may be completely different. Wardhaugh (1986:103) also said that "Metaphorical Code Switching has an affective dimension to it: you change the code as you redefine the situational - formal to informal, official to personal, serious to humorous, and politeness to solidarity."

Data 2:

Tony: "Ini Tory. Pacar Markus."

Tory: "Yeah, aku pacar Markus," Sahutku sambil memeluk lengan Markus. "Sorry dari tadi kurang mesra, darling."

Markus: "No problem." (Chapter 3, page 44.)

(Tony: "This is Tory. Markus's girlfriend."

Tory: "Yeah, I am Markus's girlfriend." I said as I hug Markus's arm. "Sorry the way I acted quite unromantic, darling."

Markus: "No problem."” (Chapter 3, page 44.)

\section{Analysis:}

Metaphorical Code Switching happens when Tory starts talking. When she says "Yeah, aku pacar Markus," to her friend, the topic here is about Tory's relationship with Markus. But then, when she starts a new sentence "Sori dari tadi kurang mesra, darling." to Markus, the topic suddenly changes from just talking about her relationship into how she has been acting towards him all this time which is completely different. Besides , the change in social situation here also exists. The first sentence when Tory talks with her friend, the words she uses are common words without any implicit meaning behind them. But when she suddenly talks to Markus, the word choice is different. The use of the word darling shows how social situation has changed. From talking in a common way to a romantic way and it shows the fact that Tory and Markus are have a relationship.

\subsection{The Analysis of Functions of Code Switching}

There is always a reason that triggers people to switch their language when they are in the middle of conversation. According to Appel \& Muysken (1987) there are six functions of Code Switching. They are referential function, directive function, expressive function, phatic function, metalinguistic function and poetic function. The analysis of each function used behind the code switching happening in this novel will be presented as follows:

\subsubsection{The Analysis of Referential Function}

According to Appel \& Muysken (1987:118) "Switching can serve the referential function because it often involves lack of knowledge of one language or lack of facility in that language on a certain subject." Some sentences can sometimes be more understood when we use any word from another language. Also the lack of knowledge of one language can be another reason of language switch.

\section{Data 3:}

The little girl: "Semuanya udah ambil bagasi? Kalo udah beres semua, kita jalan ke mobil." Mobil yang dimaksud 
ternyata sebuah pick-up beratap yang mirip dengan bemo dan agak bau. "Sorry. Aku bermaksud nyariin kendaraan yang lebih nyaman, tapi cuma ini yang bisa kupenuhi dengan budget$k u$." (Chapter 3, page 45)

(The little girl: "Have you guys taken all your carriers? If yes, let's go to the car." What she means by the car is a pickup truck that has roof, looks like a bemo and has a quite bad odor. "Sorry. I was trying to find a more comfortable transportation but only this that I can afford." (Chapter 3 , page 45)

\section{Analysis:}

In this sentence that is said by the little girl who is the owner of the house where they stay for a while, a code switching happens. At the first sentence she asks about their belongings and then she suddenly switches the topic to the condition of the car they are going to use. Every code switching must have a reason behind it. Apparently, the little girl switches her language from Indonesian language to English in some words she says in the second sentence such as the word budget. She uses the word budget which is English due to the lack of knowledge of one language. Indonesian people usually use budget instead of dana or anggaran in their sentence when they are trying to refer to the money which is needed to buy something.

\subsubsection{The Analysis of Directive Function}

According to Appel \& Muysken (1987:119) "Switching often serves a directive function in that it involves the hearer directly. This being directed at the hearer can take many forms. One is to exclude certain persons present from a portion of the conversation. The opposite is to include a person more by using her or his language." This function of Code Switching explains about how the code switching is chosen for conveying something directly to specific hearer whether to exclude or include more persons in the conversation. After reading every dialogue in this novel, unfortunately, the code switching that has directive function cannot be found. This is because of all the characters use languages that can be understood by each other. So when they are talking with those languages, the other character still can understand and it makes them not able to be excluded. In case of switching language used to include more people in the conversation was not found because of even though they talk in different language, in this case, the use English, Melayu and Indonesian language, they still can understand it.

\subsubsection{The Analysis of Expressive Function}

According Appel \& Muysken (1987:119),speakers emphasize a mixed identity through the use of two languages in the same discourse." By this explanation, code switching sometimes happen because people try to express their identity in front of other people.

\section{Data 4:}

Tory: "Apanya yang lucu? Selera humormu jadi turun, tau?"

Markus: "No problem. Selama bisa liat kamu punya laki." (Chapter 3, page 46)

(Tory: "What's funny? Your sense of humor is downgrading, you know?"

Markus: "No problem. As long as I can see you have a boyfriend.") (Chapter 3, page 46)

\section{Analysis:}

Expressive function is about expressing an identity of the conversant when they are having a conversation with someone. Here, the change in the language happens when Markus is 
replying to Tory "No problem. Selama bisa liat kamu punya laki." Markus changes his language unconsciously since he is familiar with those languages, English and Indonesian languages. Besides, the other reason of the code switching is located in the social background of Markus. Markus was born from two different cultures. The author of this novel does not clearly state the ethnicity of his parents but in chapter 5, page 93, there is a dialogue where Markus says, "Maksud lo, bahasa bapak gue. Kan babe gue yang bule, coy. Bukan nyokap gue." ("What you mean is my dad's language. The one who is foreigner is my dad, not my mom."). Hence, we can conclude that Markus was born in a family with various cultures. His dad is a foreigner and his mom is implicitly stated that she is Indonesian. Based on this fact, another reason why Markus unconsciously changes his language is that he is expressing his identity.

\subsubsection{The Analysis of Phatic Function}

According to Appel \& Muysken (1987), “ Often switching serves to indicate a change in tone of the conversation, and hence a phatic function. This type has been called metaphorical switching by Gumperz and Hermindez Chavez (1975)." This function of code switching appears when the conversant starts to raise their tone or they have more than one topic in their utterance.

\section{Data 5:}

Tony: "oke. Aku nggak akan main sama dia lagi."

Tory: "Jangan nyesel nanti, ya."

Tony: "Nggak akan nyesel deh. By the way, berhubung sekarang tinggal kita berdua di rumah ini..." (Chapter 8, page 126)
(Tony: "okay. I'm not going to play with him again.:

Tory: "Don't regret your choice okay."

Tony: "I won't. By the way, because it is only both of us in this house..." (Chapter 8 , page 126)

\section{Analysis:}

Code switching here happens when Tony replies his sister's warn about regretting thing in the future. When he is replying, he unconsciously changes the topics which happen to be a metaphorical code switching. According to the explanation above, phatic function itself can be considered when the conversant raises the tone of their voice or when they change the topic. Therefore, the reason of code switching made by Tony functions to change the topic or can be called as a phatic function.

\subsubsection{The Analysis of Metalinguistics Function}

According to Appel \& Muysken (1987:120), "The metalinguistic function of code switching comes into play when it is used to comment directly or indirectly on the languages involved." Scotton (in Appel \& Muysken:1987) also said "One example of this function is when speakers switch between different codes to impress the other participants with a show of linguistic skills." It can be concluded that this function of code switching exists when people switch their language to show their skill in talking with different languages to impress the people their talking with.

\section{Data 6:}

Tony: "Jangan khawatir, Bang. Nanti kalo kita semua berhasil keluar dari sini, aku usahain buat beliin Abang pick-up lagi deh."

Bang Asat: "Yang benar, Jang? Pickup kan mahal." 
Tony: "Tadak, bah. Nanti kami semua patungan, pasti bisa kebeli meskipun cuma pick-up second." (Chapter 11, page 162)

(Tony: "Don't worry, if later we successfully escape from here, I will try to buy another pick-up for you.

Bang Asat: "Are you serious, kid? But pick-up truck is expensive."

Tony: "No, uncle. All of us will gather the money. I'm sure we can buy it even though it is not a secondhand pick-up truck." (Chapter 11, page 162)

\section{Analysis:}

Different from the previous data, this dialogue between Tony and Bang Asat consists of code switching not from Indonesian language to English but from Indonesian language to Melayu since Bang Asat often talks in Melayu. The reason of this language change can be seen when Tony suddenly replies what Bang Asat said with Melayu which is based on Appel \& Muysken's theory; it is considered having Metalinguistic function. It is when the conversants change their language to show their linguistic skill. Tony is not a person who usually speaks in Melayu ; however, when he talks with Bang Asat, he tries to adjust which is indirectly showing his skill in talking in that language.

\subsubsection{The Analysis of Poetic Function}

According to Appel \& Muysken (1987:120) "Bilingual language usage involving switched puns, jokes, etc. can be said to serve the poetic function of language." This function of code switching exists when they put some poetic words like puns and jokes. Unfortunately, after reading all the dialogues in this novel, poetic function of code switching cannot be found. It is because this novel is about teenager's life and the author uses a light kind of diction, not the hard one like what we can find in poetry because the marketing target meant by the author is a teenager.

\section{Conclusions}

After passing through few processes of analysis, the result of the types of code switching and reasons behind it finally can be seen. There are two types of code switching found in the analysis. They are Situational Code Switching and Metaphorical Code Switching. There are thirty four of Code Switching found in all the dialogues written in this novel and twenty of them have Situational Code Switching as its type, also, fourteen of them are considered Metaphorical Code Switching. It explains that Situational Code Switching is more dominantly used than Metaphorical code switching. The characters in this novel are more often to switch their language to elaborate their sentences so people can understand more clearly to cover the lack of acknowledgement of one language or simply to show their language skill. Therefore, the topic change is rarely needed in their conversation and it makes the Situational Code Switching arise more often than Metaphorical Code Switching.

Every Code Switching that has been done by the characters always has function behind it. Out of six functions of Code Switching According to Appel \& Muysken (1987), only four functions were found in this analysis. They are Referential Function, Metalinguistics Function, Phatic Function and Expressive Function. Referential Function is the most used function behind the language change made by the characters. The lack of acknowledgement of their own mother tongue is the main reason why this function exists behind that Code Switching. 


\section{Bibliography}

Appel, R \& Muysken, P. (1987). Language Contact and Bilingualism. Amsterdam: Amsterdam University Press.

Wardhaugh, R. (1986). An Introduction to Sociolinguistics. UK: Blackwell Publishing.

Wardhaugh, R. (2006). An Introduction to Sociolinguistics. UK: Blackwell Publishing.

Xu, L. (2011). Permainan Maut. Jakarta: PT Gramedia Pustaka Utama. 